\title{
Synthesis, characterization and antibacterial susceptibility testing of manganese complexes of doxycyline with bipyridine and phenanthroline
}

\author{
Joshua A. OBALEYE*1 and Olufunso O. ABOSEDE ${ }^{2}$ \\ ${ }^{1}$ Department of Chemistry, University of Ilorin, P.M.B. 1515, Ilorin, Nigeria \\ ${ }^{2}$ Department of Chemistry, Federal University Otuoke, P.M.B. 126, Yenagoa, Bayelsa State, Nigeria
}

\begin{abstract}
Three manganese complexes of the antibiotic doxycyline viz.: manganese doxycyline, $\left[\mathrm{MnDox}_{2}\right] \mathrm{Cl}_{2} \cdot 2 \mathrm{H}_{2} \mathrm{O}(\mathbf{1})$, and manganese doxycyline with bipyridine, $\left[\mathrm{MnDox}_{2}(\mathrm{bpy})\right] \mathrm{Cl}_{2} \cdot 8 \mathrm{H}_{2} \mathrm{O}(\mathbf{2})$, and phenanthroline, $\left[\mathrm{MnDox}_{2}(\mathrm{phen})\right] \mathrm{Cl}_{2} \cdot 8 \mathrm{H}_{2} \mathrm{O}$ (3), as the ancillary ligand were synthesized and characterized by FT-IR, elemental analysis and electrospray mass spectroscopy. The three complexes show good solubility in DMF and DMSO. Data obtained from spectroscopic techniques used show that doxycycline coordinates to the central manganese atom through the oxygen of the amide group and the carbonyl oxygen atom of ring A while bipyridine/phenanthroline coordinates through the two diimine nitrogen atoms. The stoichiometry of manganese-doxycycline is $1: 2$ and octahedral geometry is the preferred coordination in all the complexes.
\end{abstract}

Keywords: manganese, doxycycline, coordination, antibacterial, synthesis.

\section{Introduction}

Manganese is an example of metal ions which form part of the structures of enzymes of most plants and animals which they require for growth. A human body contains a total of about $16 \mathrm{mg}$ of manganese [1]. Manganese as $\mathrm{Mn}^{2+}$ is analogous to $\mathrm{Mg}^{2+}$ except that it is redox active with $+2,+3$ and +4 oxidation states having relevance in biology [2]. At least four enzymes - the photosystem II, manganese catalase, manganese superoxide dismutase and ribonucleotide reductase use manganese complex at their catalytic centers which are required for the redox activities of these enzymes [3].

Two possible indirect interactions of manganese ions on DNA structure rather than direct coordination of the ions to DNA have been identified. The first interaction involves the neutralization of the negative charge of the phosphate backbone and stabilization of the double helical structure. The second interaction mode is the prevents DNA renaturation by interaction with sites of the bases that are not involved in base pairing [4].

NMR studies have shown that manganese has affinity for GC residue with a preference for the N7 atom of guanine $[5,6]$ and some manganese complexes interact with the intra-molecular quadruplex by a oneside external $\pi$-stacking [7, 8]. Metallochaperones are metal receptor proteins reported to act in the intracellular trafficking of metal ions [9].

Some manganese complexes have been demonstrated to possess antimicrobial properties. For instance, manganese complexes incorporating 1,10phenathroline (phen) and malonic acid (mal) (e.g. $\left[\mathrm{Mn}(\mathrm{phen})_{2}\left(\mathrm{H}_{2} \mathrm{O}\right)_{n}\right]^{2+}$ and $\left.\left[\mathrm{Mn}(\mathrm{phen})_{2}(\mathrm{mal})\right] \cdot 2 \mathrm{H}_{2} \mathrm{O}\right)$, efficiently inhibit the growth of $C$. albicans in vitro at $37{ }^{\circ} \mathrm{C}$ [10-12]. Similarly, $\mathrm{Mn}(\mathrm{II})$ complexes containing 1,10-phenanthroline and dicarboxylate ligands which possess low toxicity to mellonella larvae, VERO and
A549 mammalian cells have been reported to strongly inhibit the viability of $M$. tuberculosis strains, H37Rv and CDC1551 [12]. Manganese(II) complexes of thiosemicarbazones which possess low cytotoxicity were reported as potential anti - M. tuberculosis agents. Their selectivity index (SI) values were comparable or higher than first line drugs tuberculosis drugs [13]. The activities of these manganese complexes were attributed to high oxidation potentials, suggesting that biological activity might be a function of redox processes [14]. Under conditions of oxidative stress, manganese can also act as a cofactor substitute for iron in ironcontaining enzymes [15].

The attention of scientists have also been drawn to the possible in vivo application of manganese(II) macrocycles in pain management [16] while some manganese porphyrin complexes have shown biological activity such as SOD-mimics with low aqueous toxicity [17]. Some other manganese-porphyrin complexes cleave DNA by oxidative damage in the presence of oxygen donors [18, 19] while some are capable of catalyzing dismutation of the superoxide anion and are a current focus for developing SOD mimics as drugs because of their low in vitro toxicity [20].

In our continuous effort to investigate the effect of complexation of metal ions to biologically relevant ligands [21-25], we have synthesized manganesedoxycycline complex and mixed doxycycline manganese complexes with bipyridine and phenanthroline and characterized them by FT-IR, elemental analysis and electrospray mass spectroscopy. The rationale was based on the aforementioned vital roles manganese and its compounds play in biological systems, and the pleiotropic properties of tetracyclines.

* Corresponding author. E-mail address: jobaleye@yahoo.com; jobaleye@unilorin.edu.ng (Joshua A. Obaleye) 


\section{Experimental}

\subsection{Materials and measurements}

Doxycycline hyclate was a gift from Neimeth International Pharmaceuticals Plc, Nigeria and fresh solutions were used to ensure stability while 2,2'bipyridine and 1,10-phenanthroline monohydrate were from SDFCL, India. All other chemicals and reagents are of analytical grade and used without further purifications. Infrared spectra were recorded on Shimadzu FT-IR-8400 on samples pressed in $\mathrm{KBr}$ pellets.

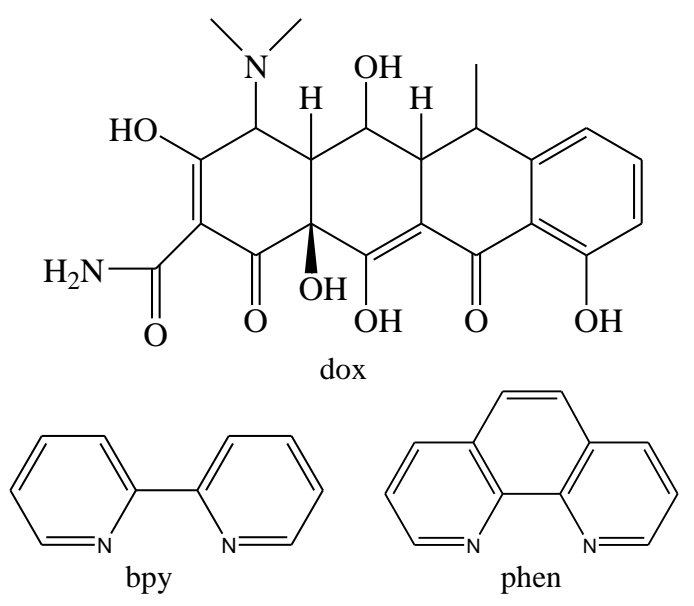

Scheme 1. Doxycycline (dox), 2, 2'-bipyridine (bpy) and 1, 10-phenanthroline (phen).

\subsection{Syntheses of the complexes}

[MnDox 2$] \mathbf{C l}_{2} \cdot 2 \mathrm{H}_{2} \mathrm{O}$ (1). $2 \mathrm{mmol}$ of Doxycycline hyclate and $1 \mathrm{mmol}$ of $\mathrm{MnCl}_{2} \cdot 4 \mathrm{H}_{2} \mathrm{O}$ were stirred in methanol for 5 hours at room temperature. The resulting yellow solution was filtered, and the filtrate was allowed to evaporate slowly at room temperature. The precipitated off-white crystals were then filtered and washed with methanol before vacuum drying.

Calculated for $\left[\mathrm{MnDox}_{2}\right] \mathrm{Cl}_{2} \cdot 2 \mathrm{H}_{2} \mathrm{O}(\%): \mathrm{C}, 50.39 ; \mathrm{H}$, 4.81; N, 5.34. Found (\%): C, 51.23; H, 5.50; N, 5.29. FT-IR $\left(\mathrm{KBr}, v / \mathrm{cm}^{-1}\right)$ : 1672.34, 1614.47, 1587.47, 1550.82, 1531.53, 1518.03, 1454.38, 1373.36, 1350.22, $1315.50,1240.27,1201.69,1172.76,1139.97,1089.82$, $1062.81, \quad 1035.81,993.37,939.36,885.36,850.64$, 821.70, 800.49, 783.13, 707.90, 667.39, 621.10, 563.23, 542.02, 532.37, 497.65, 434.00, 406.99. ESI-MS: $\left[\mathrm{Mn}+3(\text { Dox })-1 \mathrm{H}_{2} \mathrm{O}\right]^{2+}=686,\left[\mathrm{Mn}+2(\mathrm{Dox})+\mathrm{H}_{2} \mathrm{O}\right]=$ 964.9. Decomposition temperature: $203-205^{\circ} \mathrm{C}$.

[MnDox $(\mathbf{M p y})] \mathrm{Cl}_{2} \cdot \mathbf{8 H}_{2} \mathrm{O}$ (2). A mixture of $1 \mathrm{mmol}$ of Doxycycline hyclate and $1 \mathrm{mmol}$ of $\mathrm{MnCl}_{2} \cdot 4 \mathrm{H}_{2} \mathrm{O}$ was stirred in methanol for 1 hour followed by addition of 1 mmol of 2,2'-bipyridine and further stirring for another 3 hours at room temperature. The resulting yellow solution was filtered, and the filtrate was allowed to evaporate slowly at room temperature. The precipitated off-white crystals were then filtered and washed with methanol before vacuum drying. Calculated for $\left[\mathrm{MnDox}_{2}(\mathrm{bpy})\right] \mathrm{Cl}_{2} \cdot 8 \mathrm{H}_{2} \mathrm{O}(\%): \mathrm{C}, 49.40 ; \mathrm{H}, 5.37 ; \mathrm{N}$, 6.40. Found (\%): C, 48.58; H, 4.82; N, 5.87. UV-Vis $\left(\mathrm{H}_{2} \mathrm{O}, \mathrm{nm}\right): 232,280,344$. FT-IR $\left(\mathrm{KBr}, v / \mathrm{cm}^{-1}\right)$ : 1672.34, 1664.62, 1612.54, 1599.04, 1550.82, 1531.53, 1510.31, 1500.67, 1446.66, 1375.29, 1352.14, 1315.50,
1242.20, 1201.69, 1172.76, 1139.97, 1089.82, 1058.96, $1035.81,1010.73,995.30,939.36,904.64,885.36$, 850.64, 819.77, 800.49, 773.48, 734.90, 707.90, 667.39, 623.03 565.16, 545.87, 532.37, 499.58, 459.07, 435.93. Decomposition temperature: $205-206^{\circ} \mathrm{C}$.

[MnDox2(phen) $] \mathrm{Cl}_{2} \cdot \mathbf{8 H}_{2} \mathrm{O}$ (3). A mixture of $1 \mathrm{mmol}$ of Doxycycline hyclate and $1 \mathrm{mmol}$ of $\mathrm{MnCl}_{2} \cdot 4 \mathrm{H}_{2} \mathrm{O}$ in methanol was stirred for 1 hour followed by addition of $1 \mathrm{mmol}$ of 1,10-phenanthroline and further stirring for another 3 hours at room temperature. The resulting yellow solution was filtered, and the filtrate was allowed to evaporate slowly at room temperature. The precipitated off-white crystals were then filtered and washed with methanol before vacuum drying. Calculated for $\left[\mathrm{MnDox}_{2}\right.$ (phen) $] \mathrm{Cl}_{2} \cdot 8 \mathrm{H}_{2} \mathrm{O}(\%): \mathrm{C}, 50.31$; H, 5.28; N, 6.29. Found (\%): C, 50.13; H, 5.22; N, 5.83. FT-IR $\left(\mathrm{KBr}, \quad v / \mathrm{cm}^{-1}\right): 1664.62,1612.54,1587.47$, 1570.11, 1550.82, 1533.46, 1518.03, 1496.81, 1452.45, $1425.44,1329.00,1242.20,1217.12,1170.83,1132.25$, 1062.82, 1039.67, 1003.02, 935.51m 883.43, 846.78, 825.56, 804.34, 725.26, 713.69, 665.46, 615.31, 584.45, 545.87, 499.58, 459.07, 430.14. ESI-MS: $\mathrm{Mn}+\mathrm{Dox}+2(\mathrm{Phen})=862.1$ and $[\mathrm{MnDox} 2 \mathrm{Phen}+\mathrm{Na}]^{2+}$ $=575.1$ Decomposition temperature: $207-209^{\circ} \mathrm{C}$.

\section{Results and discussion}

\subsection{Characterization}

The complex 1 was prepared from the reaction of $\mathrm{MnCl}_{2} \cdot 4 \mathrm{H}_{2} \mathrm{O}$ with doxycycline while complexes $\mathbf{2}$ and $\mathbf{3}$ were prepared from the reactions of $\mathrm{MnCl}_{2} \cdot 4 \mathrm{H}_{2} \mathrm{O}$ with doxycycline and bipyridine or phenanthroline for complex $\mathbf{2}$ and $\mathbf{3}$ respectively. All the complexes were obtained in good yield and characterized by elemental analysis, FT-IR and thermal profile.

The results of the elemental analyses are in accordance with the proposed formula: $\left[\mathrm{MnDox}_{2}\right] \mathrm{Cl}_{2} \cdot 2 \mathrm{H}_{2} \mathrm{O}(\mathbf{1}),\left[\mathrm{MnDox}_{2}\right.$ (bpy) $] \mathrm{Cl}_{2} \cdot 8 \mathrm{H}_{2} \mathrm{O}$ (2) and $\left[\mathrm{MnDox}_{2}\right.$ (phen) $] \mathrm{Cl}_{2} \cdot 8 \mathrm{H}_{2} \mathrm{O}(\mathbf{3})$ where Dox, bpy and phen are doxycyline, bipyridine and phenanthroline respectively.

Complexes $\mathbf{1}$ and $\mathbf{3}$ were also characterized by ESIMS in positive ionization mode. Complex 1 has peaks corresponding to $\left[\mathrm{Mn}+3(\mathrm{Dox})-1 \mathrm{H}_{2} \mathrm{O}\right]^{2+}=686$, $\left[\mathrm{Mn}+3(\right.$ Dox $\left.)-1 \mathrm{H}_{2} \mathrm{O}\right]=1370$ and $\left[\mathrm{Mn}+2(\right.$ Dox $\left.)+\mathrm{H}_{2} \mathrm{O}\right]=$ 964.9 while complex 3 has peaks corresponding to $[\mathrm{Mn}+$ Dox +2 (Phen) $]=862.1$ and $[\mathrm{MnDox} 2 \mathrm{Phen}+\mathrm{Na}]^{2+}$ $=575.1$. The contribution of sodium is from the mass spectrometer while the detection of three molecules of doxycycline in the structure of $\mathbf{1}$ was due to the lability of the complex.

The infrared spectra of the complexes were compared to that of the ligand and were assigned based on previous published report [21]. The stretching frequency of doxycycline hydroxyl shifted from 3452 to $3508 \mathrm{~cm}^{-1}$ in complexes $\mathbf{1}$ and $\mathbf{2}$ and $3512 \mathrm{~cm}^{-1}$ in complex $\mathbf{3}$, a shift of $46 \mathrm{~cm}^{-1}$ for complexes $\mathbf{1}$ and $\mathbf{2}$ and $60 \mathrm{~cm}^{-1}$ for complex 3 . However, the amide $\mathrm{NH}_{2}$ band at $3331 \mathrm{~cm}^{-1}$ is nearly unchanged in the complexes except in complex 3. This suggests that coordination took place at ring $\mathrm{A}$ of the ligand and that oxygen of the hydroxyl group is involved in coordination. 
The amide I band $v(\mathrm{C}=\mathrm{O})$ of doxycycline changed shape and shifted from 1678 to $1672 \mathrm{~cm}^{-1}$ in complexes 1 and 2 and $1664 \mathrm{~cm}^{-1}$ in complex 3 suggesting the involvement of oxygen of the amide group in coordination. The carbonyl stretching $\mathrm{v}(\mathrm{C}=\mathrm{O})$ on rings $\mathrm{A}$ and $\mathrm{C}$ at $1616 \mathrm{~cm}^{-1}$ and $1587 \mathrm{~cm}^{-1}$ respectively are essentially unchanged eliminating the possibility of the participation of both carbonyl groups in coordination. Other absorptions associated to the amide group of ring A of doxycyline appear at the same frequencies for the complexes and doxycycline but with completely different shapes in the complexes indicating the participation of oxygen of the amide group in coordination. The coordination of the oxygen of the amide group of ring $\mathrm{A}$ also led to the shift in stretching frequency of $\delta\left(\mathrm{NH}_{2}\right)$ and $v\left(\mathrm{C}-\mathrm{NH}_{2}\right)$ of doxycycline from
1244 and 1219 to 1240 and 1201, 1242 and 1201 and 1242 and 1217 for complexes $\mathbf{1}, \mathbf{2}$ and $\mathbf{3}$ respectively. This confirms that oxygen of the amide group is involved in coordination to manganese.

The bands at 1500 and $1496 \mathrm{~cm}^{-1}$ of complexes 2 and 3 can be attributed to the stretching frequencies $\mathrm{v}(\mathrm{C}=\mathrm{N})$ of 2,2'-bipyridine and 1,10-phenanthroline respectively while the bands at 734 and $725 \mathrm{~cm}^{-1}$ can be attributed to the $v(\mathrm{C}-\mathrm{N}-\mathrm{C})$ stretching of the diamine moiety of complexes $\mathbf{2}$ and $\mathbf{3}$ respectively. The new absorptions at 434, 435 and $436 \mathrm{~cm}^{-1}$; 497, 499 and $499 \mathrm{~cm}^{-1}$; and at 563, 565 and $584 \mathrm{~cm}^{-1}$ in complexes $\mathbf{1}, 2$ and 3 respectively are attributed to $\mathrm{Mn}-\mathrm{O}$ bond while the ones at 459 in complexes $\mathbf{2}$ and $\mathbf{3}$ are attributed to $\mathrm{Mn}-\mathrm{N}$ bond. Similar coordination mode has been proposed for 1:1 copper complex of doxycycline [21].

Table 1. Summary of FT-IR spectra assignment of complexes $\mathbf{1}-\mathbf{3}$ (wavenumber in $\mathrm{cm}^{-1}$ )

\begin{tabular}{|l|l|l|l|l|}
\hline \multicolumn{1}{|c|}{ Doxycycline } & \multicolumn{1}{c|}{$\mathbf{1}$} & \multicolumn{1}{c|}{$\mathbf{2}$} & \multicolumn{1}{c|}{ 3 } & \multicolumn{1}{c|}{ Assignment } \\
\hline $3452,3331,3290,3217$ & $3508,3333,3288,3213$ & $3508,3333,3290,3209$ & $3512,3319,3296,3242,3200$ & N-H and O-H stretch \\
\hline 3010 & 3034 & 3024,3039 & 3082,3057 & Ar-H stretch \\
\hline 1678 & 1672,1664 & 1672,1664 & 1664 & Amide I C=O \\
\hline 1616 & 1614 & 1612 & 1612 & C=O on ring $A$ \\
\hline & 1587 & 1599 & 1587,1570 & C=O on ring $C$ \\
\hline 1244,1219 & 1240,1201 & 1242,1201 & 1242,1217 & Ring A amide group \\
\hline & $497,459,434$ & $499,459,435$ & $499,459,436$ & $\begin{array}{l}\text { Mn-O and Mn-N } \\
\text { bond }\end{array}$ \\
\hline
\end{tabular}

\subsection{Antimicrobial studies}

Table 2. Antiplasmodial activity of doxycycline, lincomycin and the complexes

\begin{tabular}{|c|c|c|c|c|}
\hline S/N & Complexes & $\begin{array}{c}\text { Concentration } \\
(\boldsymbol{\mu g} / \mathbf{m l})\end{array}$ & Relative activity to Dox & Reference \\
\hline 1. & CuDox 2 & 14 & 0.71 & 21 \\
\hline 2. & CubpyDox & 9 & 1.11 & 21 \\
\hline 3. & CuphenDox & 1.8 & 5.56 & 21 \\
\hline 4. & Cudppzdox & 1.1 & 9.09 & ND \\
\hline 6. & $\mathbf{1}$ & $>100$ & 21 & This work \\
\hline 7. & $\mathbf{2}$ & 5 & 0.10 & This work \\
\hline 8. & Reference Drug & 97 & & This work \\
\hline & Dox hyclate & 10 & & This work \\
\hline A & Lincomycin hydrochloride & $>100$ & & This work \\
\hline B & Chloroquine diphosphate & 0.02 & & \\
\hline C & & & & \\
\end{tabular}

Dox $=$ doxycycline, bpy = 2,2'-bipyridine, phen $=1.10$-phenanthroline, dppz $=$ dipyrido[3,2-a:2', 3'-c]phenazin

Table 3. Antibiotic resistance pattern of doxycycline and complexes 1-3 against test bacterial isolates (a) Staphylococcus aureus and (b) Klebsiella pneumonia

a.

\begin{tabular}{l|l|lr|l} 
Agents & \multicolumn{5}{|l}{ Zone of Inhibition (mm) against } \\
& \multicolumn{5}{|c}{ concentration in m g/ml } \\
\hline \multirow{2}{*}{ Dox } & 0.5 & 1.0 & 1.5 & 2.0 \\
\hline $\mathbf{l}$ & 15 & 15 & 16 & 17 \\
\hline $\mathbf{2}$ & 17 & 18 & 19 & 20 \\
\hline $\mathbf{3}$ & 13 & 14 & 16 & 18 \\
& 13 & 15 & 16 & 17
\end{tabular}

b.

\begin{tabular}{l|l|l|l|l} 
& \multicolumn{4}{|l}{ Zone of Inhib ition (mm) against } \\
& \multicolumn{5}{|l}{ concentration in $\mathbf{m g} / \mathbf{m l}$} \\
\hline \multirow{2}{*}{ Dox } & 0.5 & 1.0 & 1.5 & 2.0 \\
\hline $\mathbf{l}$ & 11 & 12 & 13 & 15 \\
\hline $\mathbf{2}$ & 16 & 18 & 21 & 22 \\
\hline $\mathbf{3}$ & 10 & 12 & 13 & 14 \\
\hline & 13 & 15 & 15 & 16
\end{tabular}


Among the manganese complexes, only complex 2 showed good activity which is twice as effective as the parent ligand doxycycline. The phenanthroline complex (3) and the binary complex 1 has less significant activity. While only 1 has higher inhibitory activity than doxycycline against Staphylococcus aureus, both $\mathbf{1}$ and 3 have higher inhibitory activity against Klebsiella pneumonia than doxycycline. This trend showed that the biological activity of the complexes was not a function of the planarity of the diimine ligands.

\section{Conclusions}

Three manganese complexes of the antibiotic doxycycline have been synthesized and well characterized by elemental analysis, FT-IR and electrospray mass spectroscopies. The stoichiometric ratio of manganese-doxycycline in all the complexes is $1: 2$. The three complexes possess antimicrobial activities in the same range with doxycycline against Staphylococcus aureus and Klebsiella pneumonia. Complex 2 exhibited the highest antiplasmodial activity among the three complexes. This complex (2) also has higher antiplasmodial activity than the corresponding copper complex.

\section{Conflict of interest}

The authors declare that there is no conflict of interests.

\section{Acknowledgements}

The authors appreciate STEP-B Project and University of Ilorin for funding; OOA appreciates Academy of Sciences for the Developing World (TWAS), DBTIndia and Prof. A.S. Kumbhar for Postgraduate Fellowship to University of Pune, India.

\section{References}

[1]. P. Chellan, P.J. Sadler, The elements of life and medicines, Phil. Trans. R. Soc. A 373 (2015) 20140182. DOI: 10.1098/rsta.2014.0182.

[2]. R. Crichton, Biological Inorganic Chemistry: An Introduction, Elsevier, Amsterdam 2008.

[3]. J. Li, S. Yang, F. Zhang, Z. Tang, Q. Shi, Z. Zhou, Synthesis, crystal structure and properties of binuclear manganese complex [(bipy $)_{2} \mathrm{Mn}_{2}(\mu-$ $\left.\mathrm{O})(\mu-\mathrm{Ac})_{2}\left(\mathrm{H}_{2} \mathrm{O}\right)_{2}\right]\left(\mathrm{ClO}_{4}\right)_{2}$, Chin. Sci. Bull. 45 (2000) 1079-1082. DOI: 10.1007/BF02887178

[4]. A.M. Polyanichko, V.V. Andruschchenko, E.V. Chikhirzhina, V.I. Vorobev, H. Wieser, The effect of manganese(II) on DNA structure: electronic and vibrational circular dichroism studies, Nucleic Acids Res. 32 (2004) 989-996. DOI: $10.1093 /$ nar/gkh242

[5]. V. Steenwinkel, R.F. Campagnari, M. Merlini, Interactions of $\mathrm{Mn}^{2+}$ with DNA as studied by proton relaxation enhancement of solvent water, Bioploymers $20 \quad$ (1981) 915-923. DOI: 10.1002/bip.1981.360200506

[6]. J.A. Anderson, G.P.P. Kurtz, H.H. Evans, T.J. Swift, Preferential interaction of manganous ions with the guanine moiety in nucleosides, dinucleosides monophosphates, and deoxyribonuclucleic acid, Biochemistry 10 (1971) 4368-4374. DOI: 10.1021/bi00800a003

[7]. C. Vialas, G. Pratviel, B. Meunier, Oxidative damage generated by an oxo-metalloporphyrin onto the human telomeric sequence Biochemistry 39 (2000) 9514-9522. DOI: $10.1021 /$ bi000743x

[8]. A. Maraval, S. Franco, C. Vialas, G. Pratviel, M.A. Blasco, B. Meunier, Porphyrin-aminoquinoline conjugates as telomerase inhibitors, Org. Biomol. Chem 1 (2003) 921-927. DOI: 10.1039/B211634K

[9]. M.H. Gold, H.L. Youngs, M.D. Gelpee, Manganese peroxidase, in "Metal Ions in Biological Systems. Volume 37: Manganese and Its Role in Biological Processes", pp. 559-586, CRC Press, New York 2000.

[10]. R.M. Gandra, P.M. Carron, M.F. Fernandes, L.S. Ramos, T.P. Mello, A.C. Aor, M.H. Branquinha, M. McCann, M. Devereux, A.L.S. Santos, Antifungal potential of copper(II), manganese(II) and silver(I) 1,10-phenanthroline chelates against multidrug-resistant fungal species forming the Candida aemulonii complex: impact on the planktonic and biofilm lifestyles, Front. Microbiol. 8 (2017) 1257. DOI: 10.3389/fmicb.2017.01257

[11]. M. Geraghty, J.F. Cronin, M. Devereux, M. McCann, Synthesis and antimicrobial activity of copper(II) and manganese(II) $\alpha$, $\omega$-dicarboxylate complexes, Biometals 13 (2000) 1-8. DOI: 10.1023/A:1009271221684

[12]. B. Coyle, P. Kinsella, M. McCann, M. Devereux, R.O. 'Connor, M. Clynes, K. Kavanagh, Induction of apoptosis in yeast and mammalian cells by exposure to 1, 10-phenanthroline metal complexes, Toxicol. in Vitro 18 (2004) 63-70. DOI: 10.1016/j.tiv.2003.08.011

[13]. C.G Oliveira, P.D.S. Maia, C.S. Paula, R.P. Fernando, C.Q.F. Leite, R.B. Viana, A.A. Batista, O.R. Nascimento, V.M. Deflon, Manganese(II) complexes with thiosemicarbazones as potential anti-Mycobacterium tuberculosis agents, J. Inorg. Biochem. 132 (2014) 21-29. DOI: 10.1016/j.jinorgbio.2013.10.011

[14]. M. Pauraic, M. Malachy, M. Devereux, K. Kavanagh, C. Skerry, P.C. Karakousis, A.C. Aor, T.P. Mello, D. Santos, A.L.S. Santos, A.L. Souza, D.L. Campos, F.R. Pavan, Unprecedented in vitro antitubercular activity of manganese(II) complexes containing 1,10- phenanthroline and dicarboxylate ligands: Increased activity, superior selectivity, and lower toxicity in comparison to their copper(II) analogs, Front. Microbiol. 9 (2018) 1432. DOI: 10.3389/fmicb.2018.01432

[15]. N. German, F. Luthje, X. Hao, R. Ronn, C. Rensing, Microbial virulence and interactions with metals, Progr. Mol. Biol. Transl. Sci. 142 (2016) 27-49. DOI: 10.1016/bs.pmbts.2016.05.010

[16]. Z.Q. Wang, F. Porreca, S. Cuzzocrea, K. Galen, R. Lightfoot, E. Masini, C. Muscoli, V. Mollace, M. Ndengele, H. Ischiropoulos, D. Salvemini, A newly identified role for superoxide in 
inflammatory pain, Pharmacol. Exp. Ther. 309 (2004) 869-878. DOI: 10.1124/jpet.103.054154

[17]. F. Benoit-Vical, A. Robert, B. Meunier, In vitro and in vivo potentiation of artemisinin and synthetic endoperoxide antimalarial drugs by metalloporphyrins, Antimicrob, Agent. Chemoth. 44 (2000) 2836-2841.

DOI: 10.1128/AAC.44.10.2836-2841.2000

[18]. G. Pratviel, J. Bernadou, B. Meunier, Selective DNA cleavage by metalloporphyrin derivatives, in "Metal Ions in Biological Systems. Vol. 33: Probing of Nucleic Acids by Metal Ion Complexes of Small Molecules" pp. 399-426, CRC Press, New York 1996.

[19]. C. Vialas, G. Pratviel, C. Claparols, B. Meunier, Efficient oxidation of $2^{6}$-deoxyguanosine by $\mathrm{Mn}$ TMPyP/KHSO 5 to imidazolone $\mathrm{dlz}$ without formation of 8-oxo-dG, J. Am. Chem. Soc. 120 (1998) 11548-11553. DOI: 10.1021/ja981597+

[20]. Z. Xin, S.J. Lippard, New metal complexes as potential therapeutics, Curr. Opin. Chem. Biol. 7 (2003) 481-489. DOI: $10.1016 / \mathrm{S} 1367-$ 5931(03)00081-4

[21]. O.O. Abosede, N.A. Vyas, S. Singh, A.S. Kumbhar, A. Kate, A.A. Kumbhar, A. Khan, A. Erxleben, P. Smith, C. de Kock, F. Hoffmann, J.A. Obaleye, Copper (II) mixed ligand polypyridyl complexes with doxycycline-structures and biological evaluation, Dalton Trans. 45 (2016) 3003-3012. DOI: 10.1039/c5dt04405g

[22]. A.C. Tella, J.A. Obaleye, Divalent metal complexes of 4-amino-N-pyrimidin-2ylbenzene sulphonamide and their antimalarial activities against Plasmodium berghei, Bull. Chem. Soc. Ethiop. 25 (2011) 371-380. DOI: $10.4314 /$ bcse.v25i3.68589

[23]. J.A. Obaleye, R.M. Caira, A.C. Tella, Synthesis, characterization and crystal structure of a polymeric Zinc(II) complex containing the antimalarial quinine as ligand, J. Chem. Crystallogr. 37 (2007) 707-712. DOI: 10.1007/s10870-007-9236-3

[24]. J.A. Obaleye, C.L. Orjiekwe, D.A. Edwards, Cobalt (II) and nickel (II) complexes of 1,5diccinamyl-2-4-diaza-1,3,5-pentanetrione, Bull. Chem. Soc. Ethiop. 13 (1999) 31-38. DOI: 10.4314/bcse.v13i1.21053

[25]. J.A. Obaleye, C.L. Orijekwe, O. Famurewa, Synthesis, characterization and antimicrobial activity of cobalt (II) and nickel (II) complexes of acetyl derivatives of urea and thiourea, Indian $\mathrm{J}$. Chem. 34A (1995) 310-312.

Received: 08.04.2019

Received in revised form: 02.07.2019

Accepted: 04.07.2019 